\title{
THE INFLUENCE OF SULPHATES AS MANURE UPON THE YIELD AND FEEDING VALUE OF CROPS.
}

\author{
By T. S. DYMOND, F.I.C., F. HUGHES, AND C. W. C. JUPE.
}

AN agricultural problem to which little attention has been directed is the relation of the supply of combined sulphuric acid in the soil to the growth of crops. Field experiments upon the value of gypsum and sulphate of iron have been made, and artificial manures containing sulphates are constantly being used, but the specific effect of the combined sulphuric acid in these materials seems never to have been sufficiently investigated. Indeed, any useful effect produced by gypsum has been ascribed to indirect action, e.g., the liberation of other constituents from insoluble soil compounds.

Yet sulphur is an essential element for plants, and takes as important a position as phosphorus in their quantitative composition. According to published analyses the following crops contain in lbs. per acre :-

\begin{tabular}{|c|c|c|c|c|c|}
\hline & Sulphur & Phosphorus & & Sulphur & Phosphorus \\
\hline $\begin{array}{l}\text { Barley ........... } \\
\text { Oats............ } \\
\text { Maize....... } \\
\text { Meadow bay } \\
\text { Red clover... }\end{array}$ & $\begin{array}{l}6 \cdot 1 \\
8 \cdot 0 \\
3 \cdot 8 \\
5 \cdot 7 \\
9 \cdot 1\end{array}$ & $\begin{array}{r}9 \cdot 0 \\
8 \cdot 4 \\
7 \cdot 9 \\
5 \cdot 3 \\
10 \cdot 9\end{array}$ & $\begin{array}{l}\text { Vetches ....... } \\
\text { Beans ......... } \\
\text { Swedes _..... } \\
\text { Cabbages } \\
\text { A }\end{array}$ & $\begin{array}{r}3 \cdot 9 \\
9 \cdot 3 \\
17 \cdot 8 \\
32 \cdot 9 \\
10 \cdot 8\end{array}$ & $\begin{array}{r}5 \cdot 6 \\
12 \cdot 7 \\
9 \cdot 9 \\
25 \cdot 3 \\
10 \cdot 6\end{array}$ \\
\hline & & & AVERAGE... & $10 \cdot 8$ & $10 \cdot 6$ \\
\hline
\end{tabular}

The yield of a crop is likely to depend as much upon a sufficiency of available sulphuric acid as upon that of phosphoric acid in the soil, and to constitute a sufficiency, as the foregoing figures shew, more of the former will be often required than of the latter.

There is also another question involved. Sulphur is an invariable constituent of the albuminoids found in crops, and, unless it can be 
shown that sulphur can be replaced by oxygen in these compounds, a sufficiency of combined sulphuric acid in the plant food is necessary to the formation of a high percentage of albuminoid. It is therefore not only a question of yield, but also of feeding value. We will first discuss the supply of combined sulphuric acid in the soil and its influence on the yield of crops, and afterwards its relation to feeding value.

In south-east Essex, the existence of sulphates in clay soils is often manifest. On a dry bank under a hedge a white efflorescence of gypsum may frequently be observed. On a bright day after rain the soil of a field will become "capped" with the same substance. In superficial layers of the London clay star-shaped clusters of selenite crystals are often found. Surface-well waters in the same district contain enormous quantities of the sulphates of calcium and magnesium, the latter predominating. One such water from Wickford that we examined had a permanent hardness equal to 93 parts of calcium sulphate per 100,000, and another from Ingrave as much as 112 parts. Rudler suggests that the source of the calcium sulphate is oxidation of the pyrites in the London clay, and reaction of the resulting sulphuric acid with fossils and septaria. It might however be due to the reaction of the sulphuric acid of rain with the calcium carbonate of the surface soil, for the London clay, being almost impermeable, prevents the draining away of the sulphate formed and the solution becomes more concentrated by evaporation. Even a permeable subsoil may contain more combined sulphuric acid than the surface soil. Thus a boulder clay subsoil at Cressing was found to contain 0.055 per cent. sulphuric acid $\left(\mathrm{SO}_{3}\right)$, the top soil only 0.028 .

A number of Essex soils have been analysed fur sulphuric acid. The following table gives the results compared with phosphoric acid, the numbers representing the percentage extracted by strong acid from the fine earth, air-dried, from the top nine inches of soil.

It will be seen that the combined sulphuric acid in Essex soils is very sinall and is always less than, and averages two-fifths of, the phosphoric acid. It will be suggested that the reason why these soils, though notoriously deficient in phosphoric acid, are not supposed to be deficient in sulphuric acid is that the latter is mostly in an available state. This is not the case; the soil from Gt. Oakley extracted by a one per cent. solution of citric acid gave only 0.006 per cent. "available" sulphuric acid. It must be supposed that the greater part of the sulphuric acid is in the form of insoluble basic sulphates of 
T. S. Dymond, F. Hughes and C. W. C. Jupe 219

aluminium, etc. The small amount of available sulphuric acid in these soils is accounted for by its loss by drainage, sulphates being always one of the most abundant constituents of drainage waters. The sulphuric acid lost by drainage in the 20 inch drain gauge in the Barn Field at Rothamsted was found in 1896 to amount to $71.4 \mathrm{lbs}$. per acre', which would mean a loss to the soil of $\cdot 001$ per cent.

Percentage of Sulphuric and Phosphoric Acids in Essex Soils.

\begin{tabular}{|c|c|c|c|c|c|}
\hline Locality & $\begin{array}{c}\text { Sulphuric } \\
\text { Acid. } \\
\mathrm{SO}_{3}\end{array}$ & $\begin{array}{c}\text { Phosphoric } \\
\text { Acid. } \\
\mathrm{P}_{2} \mathrm{O}_{5}\end{array}$ & Locality & $\begin{array}{c}\text { Sulphuric } \\
\text { Acid. } \\
\mathrm{SO}_{8}\end{array}$ & $\begin{array}{c}\text { Phosphoric } \\
\text { Acid. } \\
\mathrm{P}_{2} \mathrm{O}_{5}\end{array}$ \\
\hline 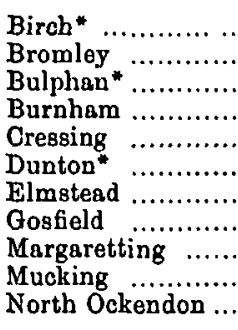 & $\begin{array}{l}0.038 \\
0.062 \\
0.030 \\
0.080 \\
0.028 \\
0.028 \\
0.043 \\
0.060 \\
0.056 \\
0.029 \\
0.039\end{array}$ & $\begin{array}{l}0 \cdot 120 \\
0 \cdot 250 \\
0 \cdot 100 \\
0 \cdot 180 \\
0 \cdot 060 \\
0 \cdot 140 \\
0 \cdot 080 \\
0 \cdot 240 \\
0 \cdot 160 \\
0 \cdot 120 \\
0 \cdot 170\end{array}$ & 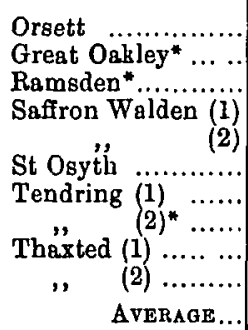 & $\begin{array}{l}0.050 \\
0.048 \\
0.080 \\
0.093 \\
0.079 \\
0.043 \\
0.035 \\
0.050 \\
0.040 \\
0.045 \\
0.051\end{array}$ & $\begin{array}{l}0.080 \\
0.100 \\
0.220 \\
0 \cdot 110 \\
0 \cdot 090 \\
0 \cdot 090 \\
0.060 \\
0.160 \\
0.130 \\
0 \cdot 150 \\
0 \cdot 134\end{array}$ \\
\hline
\end{tabular}

- These soils overlie London clay subsoils.

As these analyses point clearly to possible deficiency of sulphuric acid in a state available for crops, some experiments were carried out for the Essex Education Committee in 1896 and the following years upon the specific value of combined sulphuric acid in manures. A difficulty experienced in the experiment was the necessity of eliminating the effect of the base with which the sulphuric acid is combined. On chalky soils the effect of gypsum against no gypsum could be compared, but this was inadmissible on other soils because the lime of the gypsum would exert its own specific physical or chemical influence. On such non-chalky soils sulphate of ammonium as against chloride of ammonium was ultimately used, but the plan is not without objections, for of the sulphuric and hydrochloric acids liberated by nitrification in the soil, the latter will have greater activity in liberating other food materials from feebly soluble compounds owing to its greater ionisation in solution, besides which the formation of calcium and magnesium chlorides, as against sulphates, will render the soil more hygroscopic,

I From figures supplied by Mr A. D. Hall. 
220

Influence of Sulphates on Crops

\begin{tabular}{|c|c|c|c|c|c|c|c|c|}
\hline \multirow{5}{*}{ 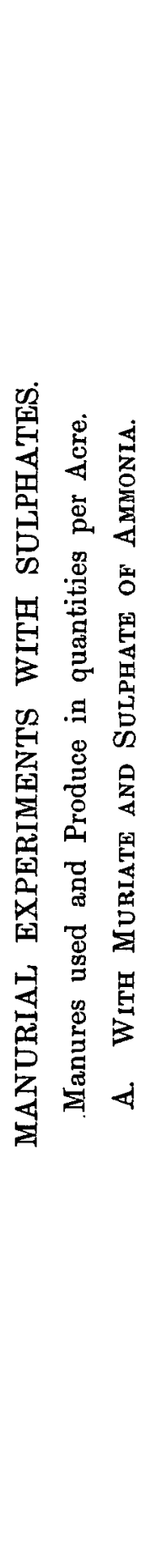 } & 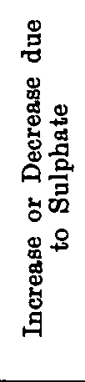 & 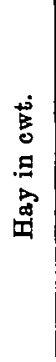 & 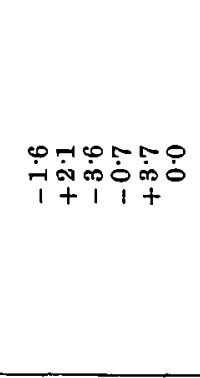 & 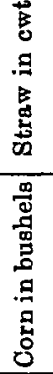 & $\stackrel{\infty}{\dot{\varphi}}$ & $\dot{\vec{i}}$ & 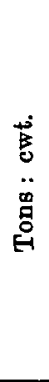 & 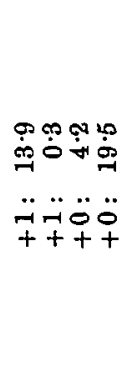 \\
\hline & 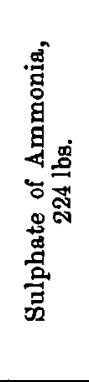 & 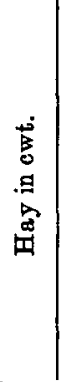 & 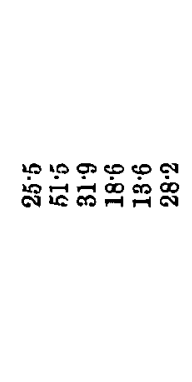 & 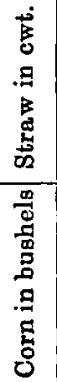 & $\stackrel{m}{\dot{m}}$ & $\dot{\sharp}$ & 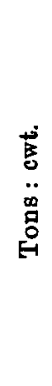 & 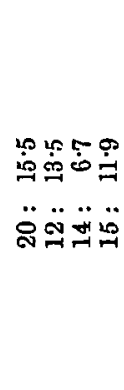 \\
\hline & 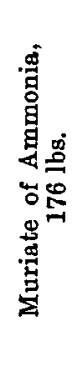 & 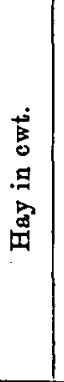 & 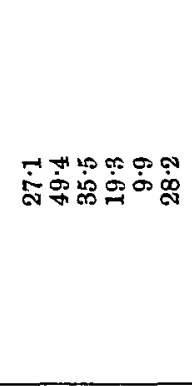 & 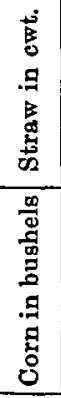 & 总 & 粱 & 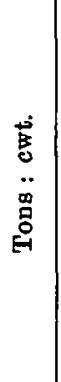 & 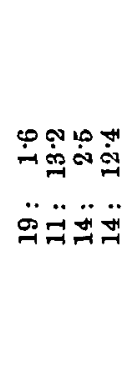 \\
\hline & & & 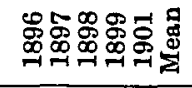 & & 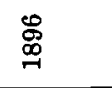 & 勇 & & 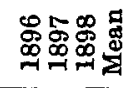 \\
\hline & & 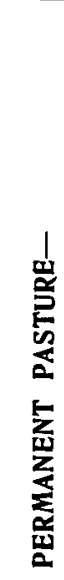 & 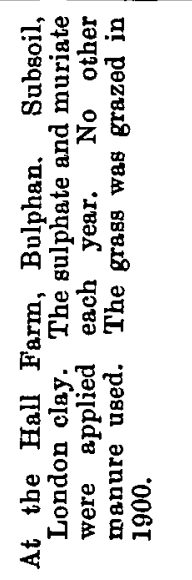 & & 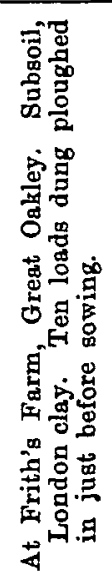 & 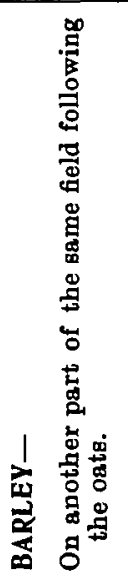 & 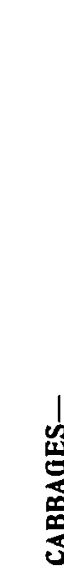 & 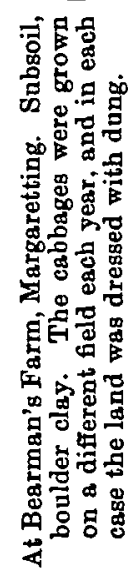 \\
\hline
\end{tabular}


T. S. Dymond, F. Hughes and C. W. C. Jupe 221

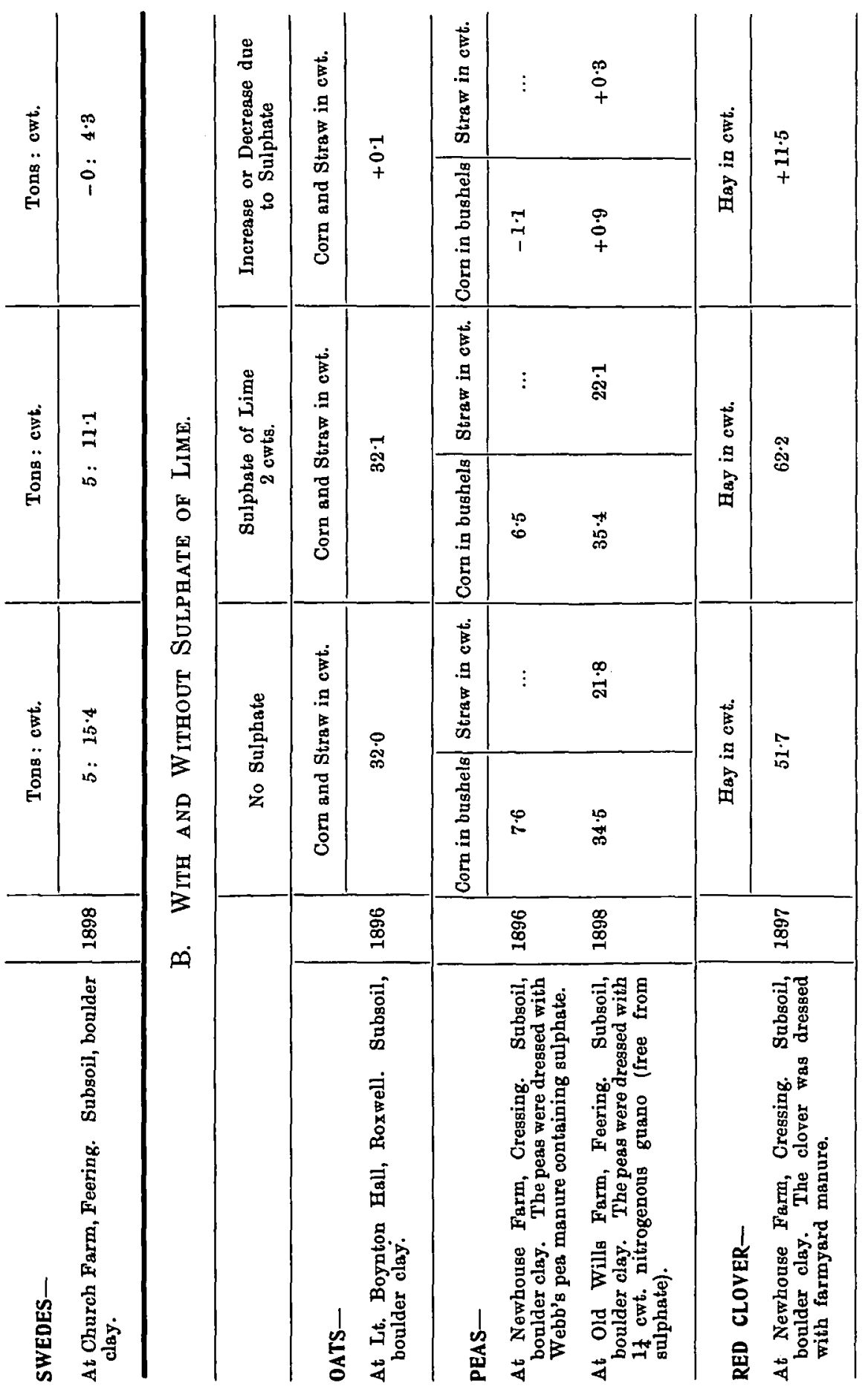


and, in dry seasons such as those during which the experiments were carried out, be certain to affect the luxuriance of the crops to some extent.

The results of the experiments are given in the tables ${ }^{1}$ on pp. 220 and 221 .

These results indicate very clearly the kind of crops that will be increased by the application of combined sulphuric acid in manures, viz. a heavy yielding crop rich in albuminoid. The oats and barley being comparatively poor in albuminoid were not benefited by sulphate manuring, indeed in the case of those grown at Gt. Oakley the chloride had a more beneficial action,-this being due either to its greater activity as a solvent or to its hygroscopic action in the soil during two dry seasons. The swedes, although a crop rich in combined sulphur, are poor in albuminoid, and were not benefited by sulphate manuring, partly however because the yield was so sinall. Cabbages, a crop which is richer in albuminoid and gives a very heavy yield, were benefited in each of the three seasons the experiment was made. Red clover, also yielding heavily and rich in albuminoid, was increased to the extent of 20 per cent. by sulphate manuring. Permanent pasture gave, on the average of five seasons' crops, precisely the same yield of hay with sulphate as with chloride of ammonium, for neither were the crops heavy nor is the percentage of albuminoid in hay high; but as might have been expected it was found that, in the year that the herbage was analysed (1897), the sulphates had had some influence upon maintaining the clover against the injurious influence of the nitrogen of the manure:-

$$
\begin{aligned}
\text { Clover on the unmanured plot } \quad=32.4 \text { per cent. } \\
" \quad " \quad \text { sulphate of ammonium }=12.6 \\
" \quad " \quad \text { chloride of ammonium }=8 \cdot 6 \quad "
\end{aligned}
$$

Peas, a crop containing more than an average amount of albuminoid, were slightly benefited when the yield was heavy, but actually injured when the crop was light and an excessive quantity of sulphate employed. That an excessive quantity of sulphate is injurious to crops

1 For carrying out these experiments the Committee were indebted to Mr Harry Mann, Bulphan, Mr Perey Stanford, Great Oakley, Mr George McMillan, Margaretting, Mr R. W. Christy, Roxwell, Mr J. W. Moss, Feering, Mr Philip Hutley, Witham and Cressing, and Mr J. W. Hepburn. In the tables the names under which the manures are known in commerce are used,-muriate and sulphate of ammonia for ammonium chloride and sulphate, and sulphate of lime for calcium sulphate (gypsum). 
T. S. Dymond, F. Hugress and C. W. C. Jope 223

seems to be the case, probably owing to its action on the physical condition of the soil. Other field experiments in Essex have shewn the deleterious effect of too large a dressing of superphosphate of lime on mangolds, even on chalky soils, and this is likely to be due to the large quantity of sulphate thus applied. In mixing manures the desirability of limiting the sulphates employed should be remembered, for a mixture of superphosphate, sulphate of ammonia and sulphate of potash, especially when sulphate of lime is added to improve the condition of the manure for sowing, must almost certainly contain an injurious proportion.

As these field experiments demonstrate that the usefulness of sulphate manuring is generally confined to heavy yielding crops containing a high proportion of albuminoid, it remains to be considered why soils so poor in available sulphate still contain sufficient for other crops, whereas the available phosphate is insufficient, although both are required by these crops in nearly equal amount. The two possible sources of supply of sulphuric acid during the growth of a crop are (1) organic sulphur compounds of the soil, and (2) rain. Each of these must be considered.

Berthelot and Andre' have shewn that in addition to the sulphates dissolved by hydrochloric acid and precipitable by barium chloride, sulphur exists in the soil in the form of ethereal sulphates, metallic sulphides, and organic nitrogen compounds of sulphur. The only method of estimating the total sulphur is therefore by combustion, the gaseous products being passed over heated sodium carbonate. By this method they obtained an amount of sulphur nearly eight times as great as that present in the soil in the form of metallic sulphates. This is probably in excess of the proportion found in soils so poor in organic matter as those of Essex; still it is important to enquire to what extent any store of combined sulphur in our own soil can be utilized by oxidation to sulphuric acid.

To investigate this question two glass tubes were filled with a London clay soil (from Birch), both sufficiently moist. Each was sterilized by heating at $100^{\circ}$ for an hour and a-half on two consecutive days. One of the two soils was then inoculated with the washings from a little fresh soil. Sterilized air was then passed through each tube for 70 hours at the rate of three litres an hour. Each soil was finally extracted with hydrochloric acid and the sulphuric acid deter-

1 Ann. de Chim. et de Phys. T. 15, p. 119. 
mined. The sterile soil was found to contain 0.026 per cent. sulphuric acid, the inoculated soil 0.034 per cent., an increase of 0.008 per cent. by oxidation due to bacterial action ${ }^{1}$. It is therefore clear that the percentage of sulphuric acid extracted from a soil by hydrochloric acid no more represents the supply available for a crop during its whole period of growth, than the percentage of nitric acid represents the available nitrogen.

We turn now to the question of the supply of sulphuric acid in rain. A sample of rain-water collected at this laboratory gave on analysis 1 part of sulphuric acid per 100,000 , which for the average annual rainfall between $1895-1903(=500,000$ gallons per acre) amounts to $50 \mathrm{lbs}$. per acre, a quantity sufficient for the heaviest crops! But this is greater than that in purely rural districts. The sulphuric acid collected in the small rain gauge at Rothamsted equals 18.5 lbs. per acre ${ }^{z}$, a quantity sufficient for certal crops and permanent pasture, but not for heavy crops of roots or cluver. Of course on arable land a considerable part of this will be lost by drainage, but on permanent pasture the quantity is such as to provide for storage of combined sulphur taking place, so that tillage crops may have sulphuric acid produced by the gradual oxidation of the organic compounds stored in previous years when the land was under grass, as well as the sulphuric acid of rain, to depend upon.

Evidence of the sufficiency of the supply of sulphuric acid by rain for most crops, where loss by drainage was prevented, was obtained by a series of pot cultures, the results of which are given in the accompanying table. The sand for the cultures of maize and clover was washed with distilled water till practically free from soluble sulphate. Analysis shewed that it still contained 0.00075 per cent. total sulphuric acid, which amounted to 0.1 gram for the whole pot full of sand ( $32 \mathrm{lbs}$.). The sand used in other cultures was probably still more free, as it was first washed with hydrochloric acid and then with distilled water till free from acid. The soils used were obtained from Mucking and from Cressing, and contained 0.028 and 0.029 per cent. of sulphuric acid respectively. Each pot was manured with 5 grams calcium carbonate and 1 gram magnesium carbonate, mixed into the sand or soil, and a solution was applied in small portions from time to time containing 5 grams potassium nitrate and 2 grams

1 For an account of sulphur bacteria see Coun's Agricultural Bacteriology, p. 59.

2 From figures supplied by Mr A. D. Hall. 
T. S. Dymond, F. Hughes and C. W. C. Jupe 225 of ammonium phosphate. The sulphate pots received 2 grams of gypsum along with the calcium and magnesium carbonate.

Field of Crops grown in Sand and Soil.

\begin{tabular}{|c|c|c|c|c|c|}
\hline \multicolumn{2}{|r|}{ Crop } & Grown in & Manured with & $\begin{array}{l}\text { Produce as } \\
\text { gathered } \\
\text { in grams. }\end{array}$ & $\begin{array}{l}\text { Dried at } 100^{\circ} \\
\text { in grams. }\end{array}$ \\
\hline \multicolumn{2}{|l|}{ Vetches } & Sand & Gypsum & 38 & $17^{*}$ \\
\hline ," & ….................. & 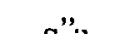 & No Gypsum & $\mathbf{3 3}$ & $13^{*}$ \\
\hline$"$ & 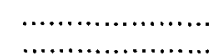 & Soil & Gypsum & $\begin{array}{l}166 \\
146\end{array}$ & $\begin{array}{l}30 \\
27\end{array}$ \\
\hline \multicolumn{2}{|c|}{ Oats (Corn and Straw)... } & Sand & Gypsum & 14 & $\cdot 8$ \\
\hline ", & $", \quad \ldots$ & ". & No Gypsum & 22 & 13 \\
\hline ", & $" \quad \ldots$ & Soil & Gypsum & 44 & 23 \\
\hline$"$ & $", \ldots$ & $"$ & No Gypsum & 51 & \\
\hline \multicolumn{2}{|l|}{ Mustard } & Sand & Gypsum & 9 & 5 \\
\hline$"$ & 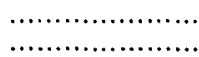 & S'il & No Gypsum & $\begin{array}{r}9 \\
98\end{array}$ & 5 \\
\hline ", & 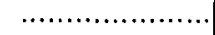 & $\begin{array}{l}\text { Soil } \\
" n\end{array}$ & $\begin{array}{l}\text { Gypsum } \\
\text { No Gypsum }\end{array}$ & $\begin{array}{l}28 \\
37\end{array}$ & $\begin{array}{l}13 \\
18\end{array}$ \\
\hline Onions. & …................. & Sand & Gypsum & 8 & + \\
\hline "' & ' & "B" & No Gypsum & 31 & $t$ \\
\hline , & \multirow{2}{*}{ 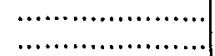 } & Soil & $\begin{array}{l}\text { Gypsum } \\
\text { No Gypsum }\end{array}$ & $\begin{array}{l}285 \\
358\end{array}$ & $\begin{array}{l}t \\
t\end{array}$ \\
\hline$"$ & & $"$ & & & \\
\hline \multicolumn{2}{|c|}{ Maize ....................... } & $\begin{array}{c}\text { Sand } \\
\text { " }\end{array}$ & $\begin{array}{c}\text { Gypsum } \\
\text { No Gypsum }\end{array}$ & $\begin{array}{l}437 \\
155\end{array}$ & $\begin{array}{l}73 \pm \\
22 \S\end{array}$ \\
\hline \multicolumn{2}{|c|}{ Red Clover. } & $"$ & Gypsum & 49 & + \\
\hline ", & .............. & $"$ & No Gypsum & 20 & t \\
\hline
\end{tabular}

- Including roots.

+ Not determined.

‡ Weighed 101 græms, including roots.

$\S$ Weighed 34 grams, including roots.

While the pots of vetches, oats, mustard, and onions were exposed to rain, the pots of maize and clover were protected. It is in these last two series only that manuring with sulphate produced any visible increase in the crops. Of the other four series, the oats, mustard, and onions, far from being increased by the application of sulphate, were decreased, and of the crops exposed to rain the vetches alone shewed an increase. The reason for this is probably partly due to the vetches being the crops richest in proteids and requiring more sulphur in consequence for development, but chiefly to the injurious effect of the sulphate, in the case of the oats, mustard, and onions, in causing bad physical condition of the sand and soil by "capping" the surface, and thus both limiting aëration and increasing evaporation of water; the vetches, on the other hand, being a covering crop, prevented the capping from taking place. The general result of the pot cultures is 
to confirm the lesson of the field experiments, that it is only in the case of heavy yielding crops, rich in albuminoid, that useful results from sulphate manuring can be looked for, and that a large excess of sulphate is injurious owing to physical action on the soil.

Influence on Feeding Value. The object of this part of the investigation was to ascertain whether, since the albuminoid of crops contains sulphur compounds, the proportion of albuminoid, and therefore the feeding value, is increased by manuring with combined sulphuric acid. For the purpose of this enquiry, the pot-grown crops already described, and the grasses and red clover separated from the 1897 herbage of the Bulphan plots were used for analysis, together with some specimens from the experimental plots at Rothamsted kindly supplied by Mr A. D. Hall. Total nitrogen was determined by Kjeldahl's method, albuminoid nitrogen by Stuitzer's method, and total sulphur by the combustion method (see above). Several duplicate determinations were made, and the authors are satisfied that the analytical methods gave comparable results. The results of the analyses are given in the accompanying table.

The figures shew that manuring with sulphate has always increased the percentage of total sulphur in the crops. In every case but two it also increased the percentage of total nitrogen, and in every case but one the percentage of albuminoid nitrogen. The albuminoid nitrogen per cent. of total nitrogen is sometimes increased, but not always, so that the series appears at first sight to be inconclusive.

But the result of the analyses of the pot-grown crops must be considered in connexion with the yield (see p. 225). In several cases the application of sulphate, by producing an unfavourable condition in the sand or soil, checked plant development. The result would be the increase of the percentage of nitrogen, independently of any absorption of sulphate as plant food, and the probable increase of the percentage of albuminoid owing to the earlier maturity of the crop. Any conclusion must therefore be drawn only from the two pot cultures in which this source of error does not occur, viz. vetches grown in sand and soil and maize grown in sand.

In the case of the vetches, the pots were not protected from rain, and even those not manured with sulphate had therefore a considerable though insufficient supply. That the further application of sulphate increased the percentage of albuminoid as well as the total weight of the crop appears to be conclusive evidence that albuminoid formation is directly dependent on a sufficient supply of sulphate. The increased 
T. S. Dymond, F. Hughes and C. W. C. Jupe 227

absorption and percentage of total nitrogen is the natural result of the formation and storage of albuminoid.

Percentage of Nitrogen and Sulphur in Crops (dried at $100^{\circ}$ ) grown in sand and soil in Pots and also in the Field.

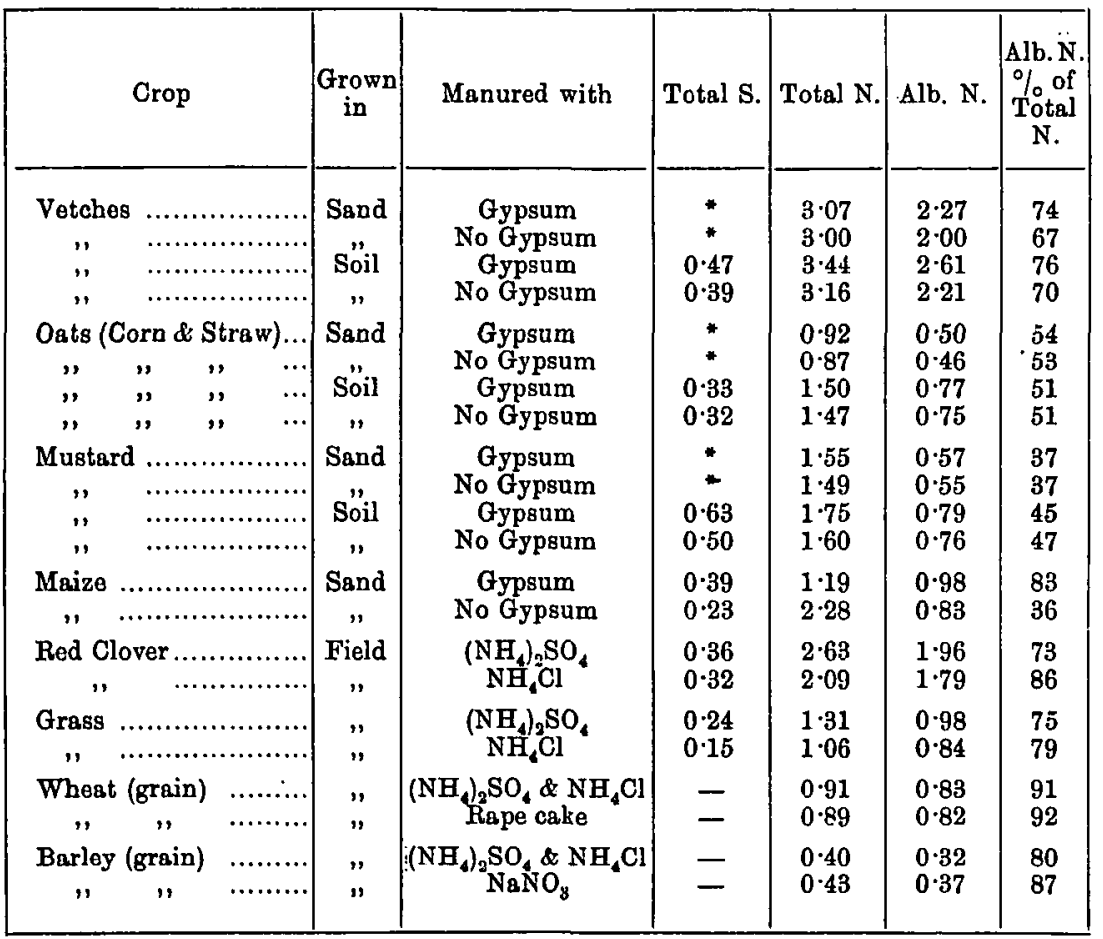

* Quantity of material insufficient for analysis.

In the case of the maize, the crop not receiving sulphate suffered from sulphate starvation to so great an extent that not only the production of albuninoid but also that of carbohydrate was greatly checked. The result was a high percentage of non-albuminoid nitrogen. In the crop receiving sulphate not only was plant development and production of carbohydrate and albuminoid enormously increased, but the percentage of albuminoid and therefore the feeding value was increased also.

By a combination of Stuitzer's and the combustion methods an attempt was made to determine whether the albuminoid sulphur was proportional to the albuminoid, as otherwise it might be objected that 
sulphur not being essential to the composition of albuminoid the formation of albuminoid could not directly depend upon the supply of sulphate. The results were as follows:-

\begin{tabular}{|c|c|c|}
\hline & $\begin{array}{c}\text { Sulphate } \\
\text { applied. }\end{array}$ & $\begin{array}{l}\text { No sulphate } \\
\text { applied. }\end{array}$ \\
\hline Total sulphur & . 0.39 & 0.23 \\
\hline Albuminoid sulphur & . $0 \cdot 15$ & $0 \cdot 11$ \\
\hline Albuminoid nitrogen & . 0.98 & 0.82 \\
\hline Ratio $\frac{\text { alb. nitrogen }}{\text { alb. sulphur }}$ & . 6.6 & $7 \cdot 5$ \\
\hline
\end{tabular}

The two ratios are, within the limits of experimental error, almost in agreement, and at any rate shew that if the sulphur in albuminoid is replaceable by oxygen it is only to a very small extent.

The results of analyses of crops grown in the field do not entirely agree with those of the pot-grown vetches and maize. There is always however the disturbing influence of the substance used on the nosulphate plot in the attempt to make it comparable with the sulphate plot, an influence which has been accentuated in the Rothamsted crops owing to the same manurial treatment having been extended over a great number of years. These results cannot therefore be held to upset the conclusions arrived at from the pot cultures.

Lastly, the question must be asked as to what are the changes in the percentage composition of a crop, associated with the increase in the percentage of albuminoid. The following aualytical results, calculated on dry matter, were obtained.

\begin{tabular}{|c|c|c|c|c|}
\hline & \multicolumn{2}{|c|}{ Grass from Bulphan } & \multicolumn{2}{|c|}{ Vetches grown in Sand } \\
\hline & With Sulphate & $\begin{array}{l}\text { Without } \\
\text { Sulphate }\end{array}$ & With Sulphate & $\begin{array}{l}\text { Without } \\
\text { Sulphate }\end{array}$ \\
\hline $\begin{array}{l}\text { Albuminoids } \ldots \ldots \ldots \ldots \\
\text { Amides, etc. } \ldots \ldots \ldots \ldots \\
\text { Sol. Carbohydrates. } \\
\text { Fibre } \ldots \ldots \ldots \ldots \ldots \ldots \ldots \\
\text { Oil } \ldots \ldots \ldots \ldots \ldots \ldots \ldots \ldots \ldots \\
\text { Ash } \ldots \ldots \ldots \ldots \ldots \ldots \ldots \ldots\end{array}$ & $\begin{array}{r}6 \cdot 12 \\
2 \cdot 06 \\
52 \cdot 09 \\
32 \cdot 40 \\
1 \cdot 02 \\
\mathbf{6} \cdot 31\end{array}$ & $\begin{array}{r}5 \cdot 25 \\
1.37 \\
50.56 \\
35 \cdot 60 \\
0.92 \\
6.30\end{array}$ & $\begin{array}{r}14 \cdot 19 \\
5 \cdot 00 \\
50 \cdot 49 \\
25 \cdot 30 \\
1 \cdot 55 \\
3 \cdot 47\end{array}$ & $\begin{array}{r}12 \cdot 50 \\
6 \cdot 25 \\
49 \cdot 47 \\
27 \cdot 10 \\
1 \cdot 28 \\
3 \cdot 40\end{array}$ \\
\hline
\end{tabular}

These results seem to point to the production of albuminoid being associated with the storage of other reserve material. One of us is preparing to continue the study of this subject from a biological point of view. 
T. S. Dymond, F. Hughes and C. W. C. Jupe 229

To sum up the general conclusions of this enquiry :-

There is not sufficient sulphuric acid in the soil or supplied by rain for heavy yielding crops rich in albuminoid, either for the production of greatest yield or the highest feeding value, and for such crops a sulphate should be included in the artificial manure. For cereal crops and for permanent pasture the soil and rain provide all the sulphuric acid necessary.

Cotnty Techical Laboratories,

Chelmsford,

February 4th, 1905. 